\title{
Analysis of Control System of Fuel Combustion in Boilers with Oxygen Sensor
}

\author{
Artur Zaporozhets ${ }^{1 *}$ \\ 1 Department of Monitoring and Optimization of Thermophysical Processes, Institute of Engineering Thermophysics of NAS of \\ Ukraine, 03057 Kyiv, 2a Zhelyabova Str., Ukraine \\ * Corresponding author, e-mail: a.o.zaporozhets@nas.gov.ua
}

Received: 24 May 2018, Accepted: 02 July 2019, Published online: 01 August 2019

\begin{abstract}
The method of fuel quality control is considered, which is based on the using of the oxygen sensor (without sensors of incomplete fuel combustion products). An algorithm for the electric drive of a fan is proposed, which is based on a step changing in the rotation speed. The choice of broadband oxygen sensor as a basis for the development of a fuel combustion control system is determined. In the course of experimental studies, the possibility of reconstructing the boiler by replacing a burner with an installed control system was demonstrated. The commissioning works were carried out with the installed system, the optimum operating conditions of the boiler were determined (with the formation of $\mathrm{CO}$ in the flue gases at a minimum level $<50 \mathrm{ppm}$ ). The technical characteristics of the boiler operation under different loads (from $10 \%$ to $100 \%$ ) are considered. Ecological and economic analysis of the developed fuel combustion control system was carried out.
\end{abstract}

Keywords

gas fuel combustion, boiler efficiency, boiler heat losses, excess air, oxygen sensor

\section{Introduction}

The problems of increasing the efficiency of fuel combustion and reducing emissions of harmful substances are particularly relevant nowadays, and in those industries where the combustion of large amounts of fuel occurs with insufficient completeness and with comparatively low efficiency. This group includes municipal boiler-houses and industrial enterprises with boiler power up to $3.5 \mathrm{MW}$.

Nowadays conventional natural gas-fired boilers exhaust flue gases direct to the atmosphere at $150-200{ }^{\circ} \mathrm{C}$. At such temperatures flue gases contain a large amount of energy and results in relatively low thermal efficiency ranging from $70 \%$ to $80 \%$. Although condensing boilers for recovering the heat in the flue gases have been developed over the past 40 years, their present market share is still less than $25 \%$ [1]. This fact indicates the need to search for new methods and tools for optimizing the operation of boilers.

Among the reasons for the poor efficiency of the boiler are the following: heat loss with exhaust gases, heat loss from chemical incomplete combustion, heat loss from mechanical incomplete combustion, heat loss from external cooling, physical heat loss of slag, etc. [2], that becomes clear from the equation of heat balance of the boiler unit.
The technical, energy and exergy analyzes, which carried out in works [3-6], showed that heat recovery from flue gases can become one of the methods for increasing the efficiency of the boiler. In the work of the authors Saidur et al. [6] one of the methods for increasing the boiler's energy efficiency is the using the electric drive of a variable speed boiler fan.

With increasing efficiency of boiler operation, it is important to remember the ecology aspects of burning carbon fuels. In works [7] the development and demonstration of two dual-species sensors for characterizing NOx abatement $\left(\mathrm{NO} / \mathrm{NH}_{3}\right)$ and combustor performance $\left(\mathrm{CO} / \mathrm{O}_{2}\right)$ are described for potential application in boiler exhaust at coal-fired electric utilities. Authors showed that the simultaneous dual-species monitoring offers potential for control of large-scale practical combustion systems.

Works $[8,9]$ demonstrated the importance of controlling $\mathrm{NO}_{x}, \mathrm{CO}$ and $\mathrm{O}_{2}$ at the biomass burning. At the same time, Pital and Mižák in [9] pointed out the existence of an interrelation between $\mathrm{CO}$ and $\mathrm{O}_{2}$ emissions.

Due to the fact that replacement of worn-out boilers with new ones requires considerable capital investments, 
a promising direction is the modernization of existing boiler units. This is a low-cost and efficient way of rational using of fuel while reducing the level of harmful substances in the flue gases. The maintenance of control systems over the composition of the air-fuel mixture with a given speed and high reliability of maintaining the excess air ratio (EAR) at the stoichiometric level remains topical [10]. In [11-13], the authors showed that the EAR value affects on the quantitative and qualitative composition of the flue gases during the combustion of natural gas, biomass and other fuels. Methods and means of quality control of heat and power equipment are also actively developing [14-16].

Improving the efficiency of fuel combustion is an important task, the solution of which will lead to the saving of fuel materials by reducing heat losses with flue gases. Development and introduction of methods and means for controlling the composition of flue gases and automatic control of the fuel combustion will increase the energy efficiency of the boiler units and improve the ecological situation by reducing harmful emissions to the atmosphere $\left(\mathrm{CO}, \mathrm{NO}_{\mathrm{x}}, \mathrm{H}_{2}\right.$, etc.), and therefore are topical scientifically applied tasks.

\section{Methods and means}

\subsection{Method for controlling of fuel combustion}

Currently, there is a significant number of schemes for automatic control of the air-fuel ratio (AFR). Most of them are aimed at simultaneous fixation of $\mathrm{CO}$ and $\mathrm{O}_{2}$ in flue gases. The disadvantage of this approach is the inconsistency of the gas, air and rarefaction rates with the inertia of smoke exhausters and fans. This creates the possibility of a short-term release of air pressure and vacuum over permissible limits, and an emergency situation as a consequence. At the same time, the analysis of CO content in flue gases does not allow to prevent the formation of incomplete combustion products $\left(\mathrm{H}_{2}, \mathrm{CH}_{4}, \mathrm{CO}, \mathrm{C}\right)$ and to reduce the concentration of harmful substances in the flue gases.

The proposed method is based on the task of improving the method of automatic control of the combustion process in boilers by continuously measuring the oxygen concentration in flue gases using an oxygen sensor, which controlling the fuel combustion regardless the change in the amount of gas entering the boiler furnace. This provides significant energy savings to the boiler room system.

The proposed method on the basis of the developed system depicted in Fig. 1 and implemented as follows. The required AFR during operation of the boiler is set by the control unit and compared with the current value obtained

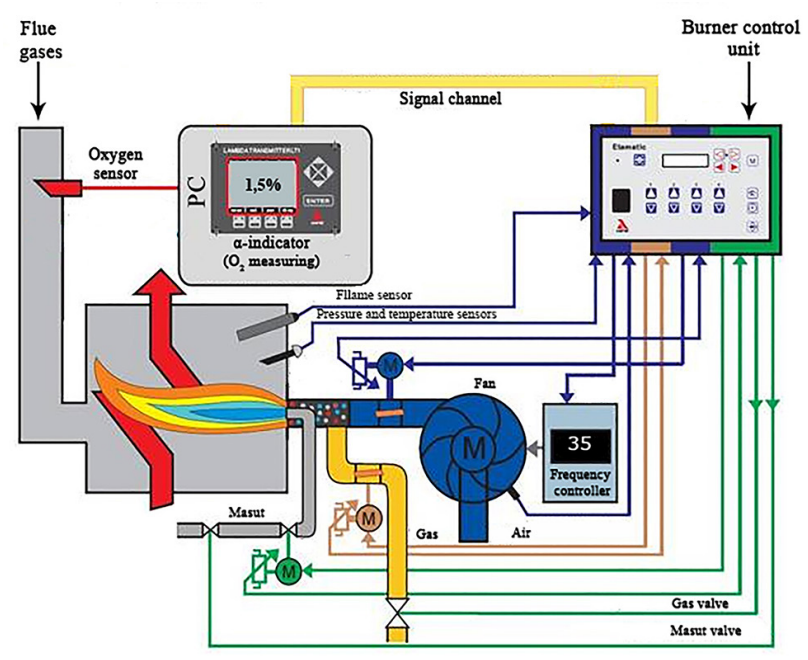

Fig. 1 Scheme of the developed system for controlling the combustion process

from the oxygen sensor. The frequency controller controls the motor of the fan. The oxygen sensor, located at the beginning of the flue path, continuously analyzes and records the oxygen concentration in the flue gases, and generates an information signal whose voltage characterizes the value of $\operatorname{EAR}(\alpha)$.

The digital $\alpha$-indicator displays on the LED strip the signal received from the oxygen sensor, and together with the previously entered information about the fuel, which is used, generates a signal which fed to the frequency regulator block, which in turn changes the mode of the fan for correcting the air supply to the burner. Thus, the required EAR value is maintained.

\subsection{Algorithm of control system functioning}

The algorithm of the automatic control system functioning for the fuel combustion in boilers by adjusting the AFR by the signals from the oxygen sensor is shown in Fig. 2.

A special feature of the algorithm is the using of frequency control, by which the amount of air supplied to the combustion zone varies smoothly. The sensor measures the concentration of oxygen in the flue gases and the system processes the receiving information. A control signal is generated depending on the received EAR value - the fan rotation frequency is reduced or increased by $0.1 \mathrm{~Hz}$ (for $\alpha>X$ or $\alpha<X$, respectively, where $X$ is the measured EAR value). After the steady-state operation of the fan is established, the system is questioned again.

$$
f(\alpha)=\left\{\begin{array}{ccc}
f_{0}-\Delta f & \text { at } & x>\alpha_{0}, \\
f_{0} & \text { at } & X=\alpha_{0}, \\
f_{0}+\Delta f & \text { at } & X>\alpha_{0}
\end{array}\right.
$$




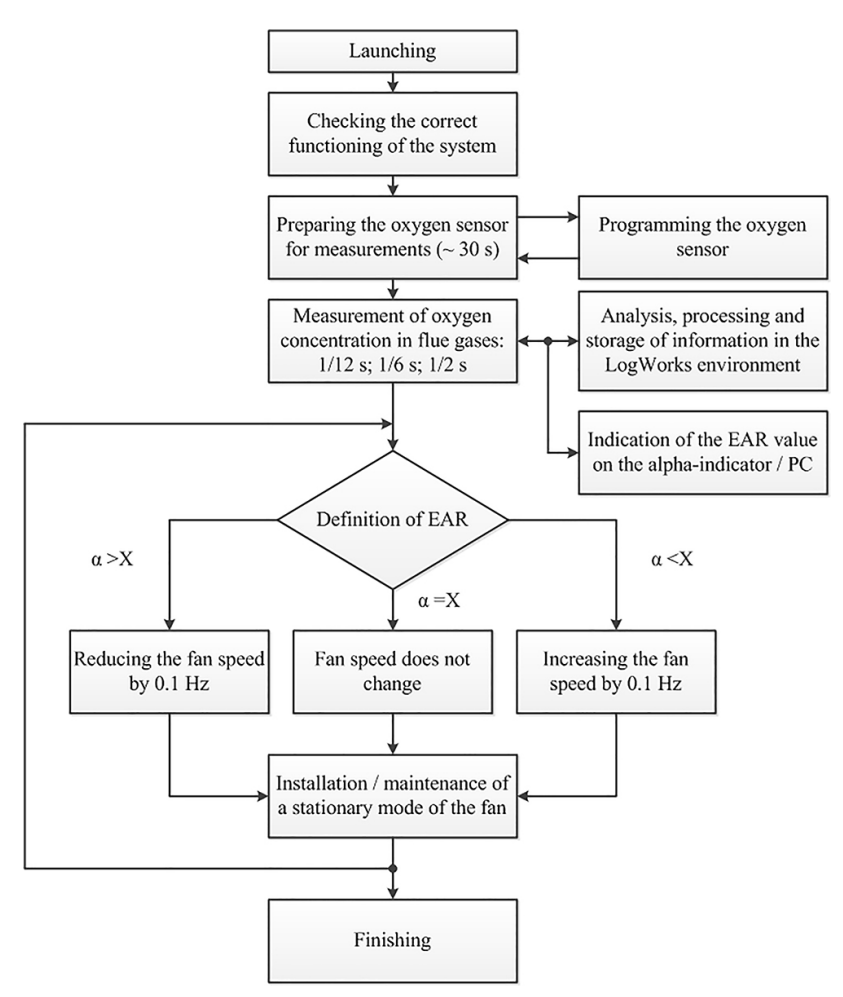

Fig. 2 The algorithm of the control system functioning on the basis of the frequency regulation of the AFR

where $f_{0}$ - the operating speed of the fan, $\Delta f$ - the step of the speed changing, $X-$ the current EAR value, and $\alpha_{0}-$ the operating EAR value.

The system also provides the setting of eight operating ranges for the frequency controller. Within these limits, the fan speed remains constant. The limits of the frequency ranges for the controller are shown in Table 1.

Table 1 demonstrates the technical features of the combustion quality control system related to the mode of operation of a blower fan.

\subsection{Features of the oxygen sensor}

For implementing the control system of the fuel combustion in boilers of low and medium power, a broadband oxygen sensor was used, which operates on the basis of the Nernst cell (Fig. 3). A significant advantage of such sensors is the $\mathrm{CO}$ oxidation on the surface of the sensor containing $\mathrm{ZrO}_{2}$ in its composition. This makes the possibility to obtain information of the actual oxygen concentration in the combustion products. The disadvantage of their application is the impossibility of detecting chemical underburning in the zone $\alpha>1$, however, as experimental data show, supporting the operation of the boiler with $\alpha \geq 1.1-1.15$ excludes the possibility of $\mathrm{CO}$ formation at a level of more than $200 \mathrm{ppm}$.
Table 1 Contrloller frequency ranges

\begin{tabular}{lcc}
\hline $\begin{array}{l}\text { Point } \\
\text { number }\end{array}$ & $\begin{array}{c}\text { Symbols on the } \\
\text { digital indicator }\end{array}$ & $\begin{array}{c}\text { Frequency range, } \\
\mathrm{Hz}\end{array}$ \\
\hline 1 & $0 . \mathrm{f}_{0}$ & from 0 to 50 \\
2 & $1 . \mathrm{f}_{1}$ & from $\mathrm{f}_{0}$ to 50 \\
3 & $2 . \mathrm{f}_{2}$ & from $\mathrm{f}_{1}$ to 50 \\
4 & $3 . \mathrm{f}_{3}$ & from $\mathrm{f}_{2}$ to 50 \\
5 & $4 . \mathrm{f}_{4}$ & from $\mathrm{f}_{3}$ to 50 \\
6 & $5 . \mathrm{f}_{5}$ & from $\mathrm{f}_{4}$ to 50 \\
7 & $6 . \mathrm{f}_{6}$ & from $\mathrm{f}_{5}$ to 50 \\
8 & $7 . \mathrm{f}_{7}$ & from $\mathrm{f}_{6}$ to 50 \\
\hline
\end{tabular}

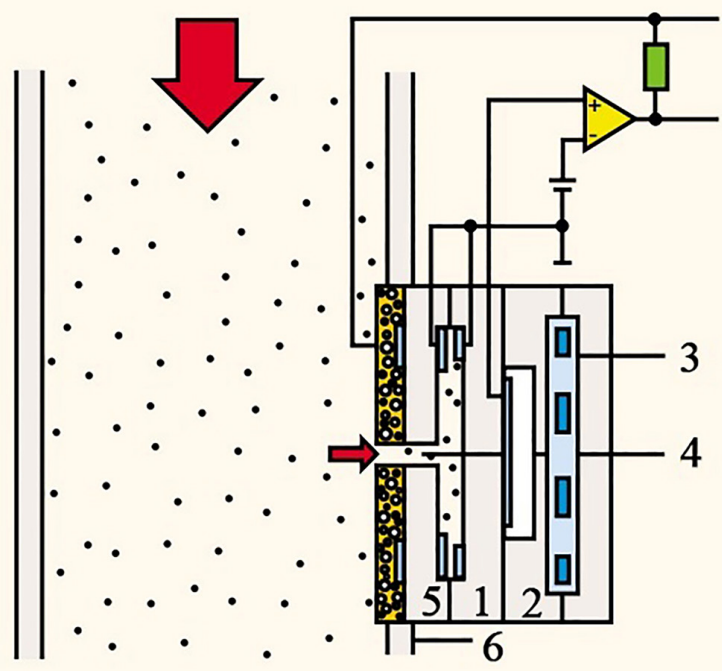

Fig. 3 Structural scheme of broadband oxygen sensor: 1 - Nernst cell, 2 - reference cell, 3 - heater, 4 - diffusion gap, 5 - pump cell, 6 - pipe wall

The design of the sensor provides the presence of two cells: measuring and pumping (Fig. 3). Through the hole in the wall of the pump cell, the flue gases enter to the measuring chamber (diffusion gap) in the Nernst cell. This configuration is characterized by a constant maintenance of the stoichiometric AFR in the diffusion gap. The electronic circuit for modulating the supply voltage maintains in the measuring chamber the composition of the mixture corresponding to $\alpha=1$. For this purpose, the pump cell removes oxygen from the diffusion gap into the external environment at the lean mixture and an excess of oxygen in the flue gases. With the enriched mixture and an insufficient amount of oxygen, the pump cell pumps oxygen ions from the environment into the diffusion gap. The direction of the current during oxygen pumping in different directions also differs (Table 2).

Thus, if conventional sensors use Nernst cell voltages for direct measurement and determine one of the two states $(\alpha>1$ or $\alpha<1)$, broadband oxygen sensors use a special circuit, controlling the pumping current of the pump 
Table 2 Some values of the output current I of the broadband oxygen sensor at different $\alpha$

\begin{tabular}{lccccccccc}
\hline $\mathrm{I}, \mathrm{mA}$ & -3 & -2 & -1 & -0.5 & 0 & 0.5 & 1 & 2 & 3 \\
\hline$\alpha$ & 0.75 & 0.82 & 0.9 & 0.95 & 1 & 1.12 & 1.27 & 1.7 & 2.6 \\
\hline
\end{tabular}

cell. The magnitude of this current determines the amount of excess air in the flue gases.

Since the work of the oxygen sensor is not dependent from the stepping in the work of the Nernst cell, the EAR can be measured in a wide range from 0.5 to 8 . Correspondingly, the monitoring of the operation of the boiler with respect to the EAR value can occur in a wide range of values, and not only at the point close to $\alpha=1$.

The using of a broadband oxygen sensor in the control system of fuel combustion has several advantages over traditional gas analyzing devices: the absence of a sample preparation system, rapid measurement of oxygen concentration (0.1-0.2 s), trouble-free operation, long service life, easy installation on different types of boilers.

\section{Results and discussion}

\subsection{Reconstruction of the boiler}

The research of the developed of automatic control system of the fuel combustion was carried out on the basis of the water heating boiler NIISTU-5. It was highlighted the main approach to improve the efficiency of this boiler - modernization of the furnace space of the boiler with a complete replacement of the morally and physically obsolete burner and automatics. The replacement was carried out on the basis of an automated block of burner PBGM0,85 ND (Fig. 4), equipped with a developed automatic control system of the fuel combustion for regulation a work of the burner and boiler as a whole.

Technical characteristics of the NIISTU-5 boiler are shown in Table 3.

\subsection{Determination of the optimal combustion mode}

Due to the fact that the developed control system of the fuel combustion does not use $\mathrm{CO}$ sensors, the main criterion of optimality has been the $\mathrm{CO}$ concentration in the flue gases. The appearance of chemical underburning (CO) determines the limit of permissible impact on the reduction of air supply. This limit is flexible and depends both from the characteristics of the burners and the load of the boiler. Its position is also affected by: the composition of the fuel (the heat of its combustion); climatic conditions; fuel and air temperature; technical condition of the equipment and many other current factors.

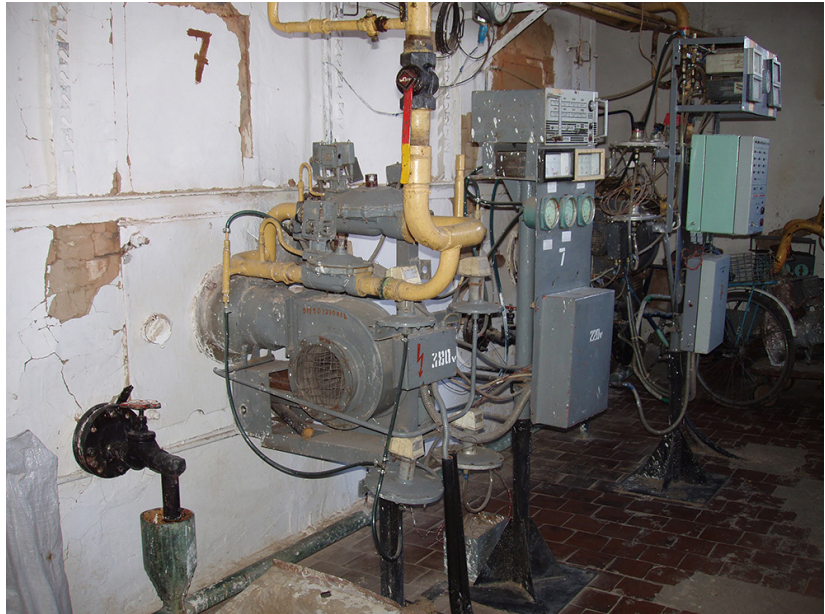

(a)

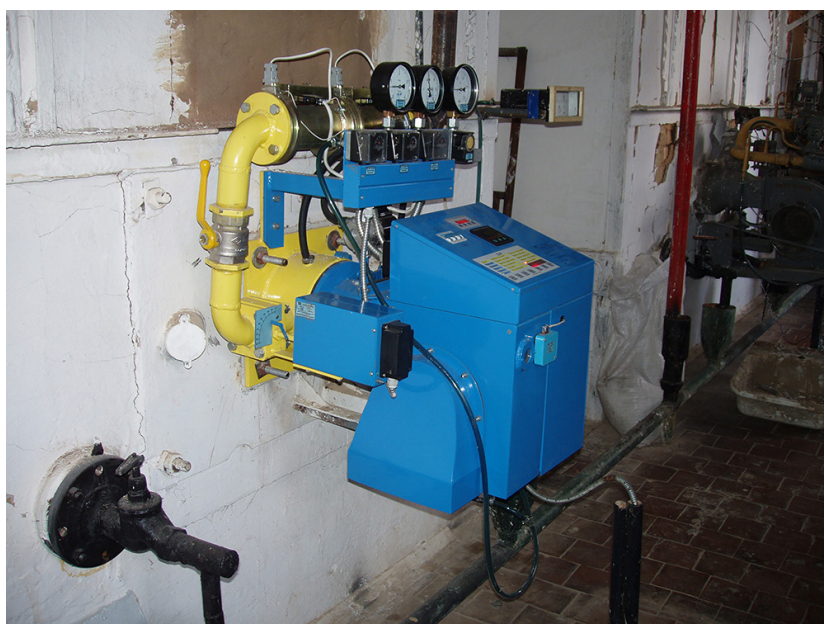

(b)

Fig. 4 Reconstruction of NIISTU-5 boiler: (a) the view before the reconstruction; (b) the view after the reconstruction

Table 3 Technical characteristics of the NIISTU-5 boiler

\begin{tabular}{lcc}
\hline Parameters & Unit & Quantity \\
\hline Volume of the heated room & $\mathrm{m}^{3}$ & 15000 \\
Nominal heating capacity & $\mathrm{MW}$ & 0.63 \\
Efficiency for gaseous fuel & $\%$ & 75 \\
Temperature of output water & ${ }^{\circ} \mathrm{C}$ & 115 \\
Dimensions & $\mathrm{cm}$ & $316 \times 210.5 \times 280$ \\
\hline
\end{tabular}

Studies of the CO concentration changing in the flue gases from the EAR in the nominal operating mode of the boiler were carried out (Fig. 5).

It was established experimentally that this boiler operates with the lowest $\mathrm{CO}$ concentration in the flue gases in the regime at $\alpha=1.2$. In the cases when the developed control system will be operate on the other boilers, it is necessary to conduct preliminary regime tests to determine the current optimality criterion. 


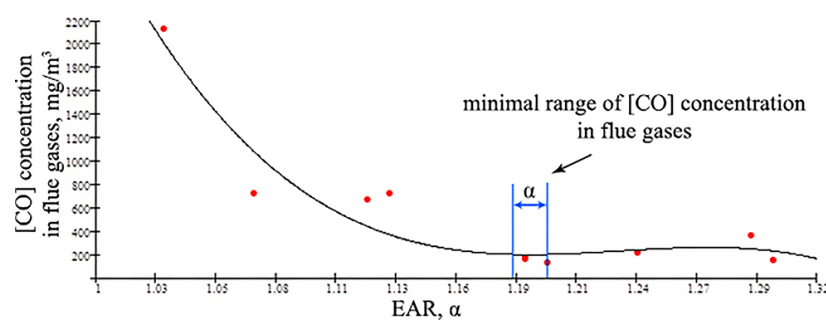

Fig. 5 Dependence of CO concentration from EAR in the flue gases

\subsection{Analysis of boiler operation on the basis of the control system}

Fig. 6 shows the experimental graphs of the dependence of the boiler power from the oxygen concentration of in the flue gases.

In the course of the experiment it was found that the control system allows to maintain the concentration of residual oxygen in the flue gases at the level of 3.3-3.5\%, which in the EAR values is 1.19-1.2. Also, the dependence of air consumption from fuel consumption in the boiler power range from $10 \%$ to $100 \%$ are established (Fig. 7).

Obtained graphs showed that the system provides a linear dependence of the air consumption from fuel consumption with the determination coefficient $R^{2}$ in the range from 0.9985 to 0.9999 .

Fig. 8-9 shows the dependence of the boiler efficiency and the heat losses with the flue gases from the boiler power with control system.
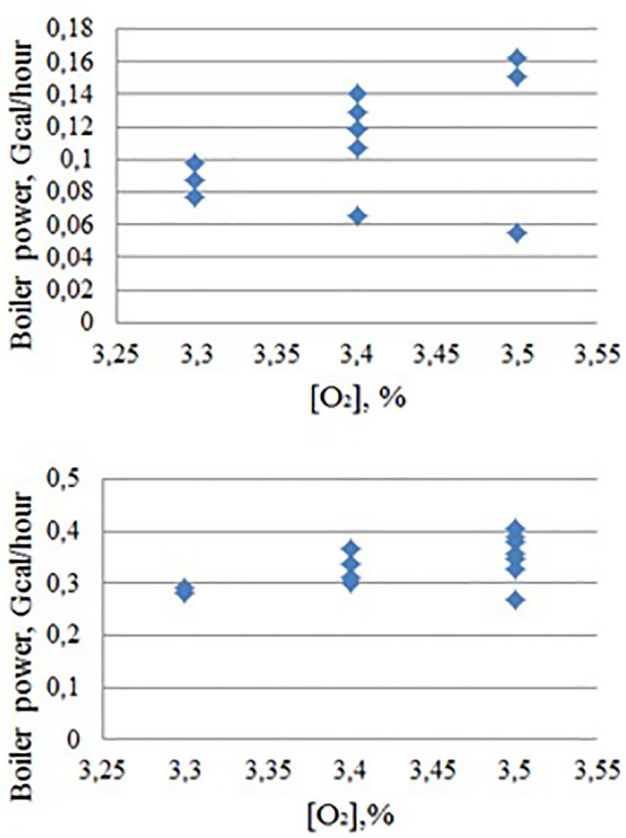

During calculating the boiler efficiency, it was taken into account that the heat losses from the boiler walls is no more than $0.25 \%$, and the heat losses with chemical underburning of the fuel is completely absent.

Thus, during the experiment it was shown that the maximum efficiency of the boiler is $\sim 97.4 \%$ achieved at the level of $10 \%$ of the rated power. Its value decreases linearly and assumes a minimum value (92.4\%) with the maximum boiler power. In this case, there are minor deviations from a linear drop in the range from 0.2 to $0.3 \mathrm{Gcal} /$ hour, which may be due to an increase in the rate of temperature growth of the flue gases. The total determination coefficient $R^{2}$ for the dependence of the boiler efficiency changing is 0.997 .

The increasing in heat losses with flue gases is also linear, with a minimum value of $2.4 \%$ at $10 \%$ boiler efficiency, and a maximum of $7.3 \%$ at $100 \%$ of the boiler efficiency. Fig. 10 shows an indicative comparison of the dependence of the boiler efficiency from its power when the boiler is operating on a mode map and using the developed system.

As can be seen from Fig. 10, the using of the automatic control system for the fuel combustion can significantly increase the boiler efficiency at any boiler load. The maximum efficiency difference occurs at $20 \%$ of the boiler load and its level is $22.1 \%$, the minimum efficiency difference occurs at the rated boiler load and its level is $6.5 \%$.
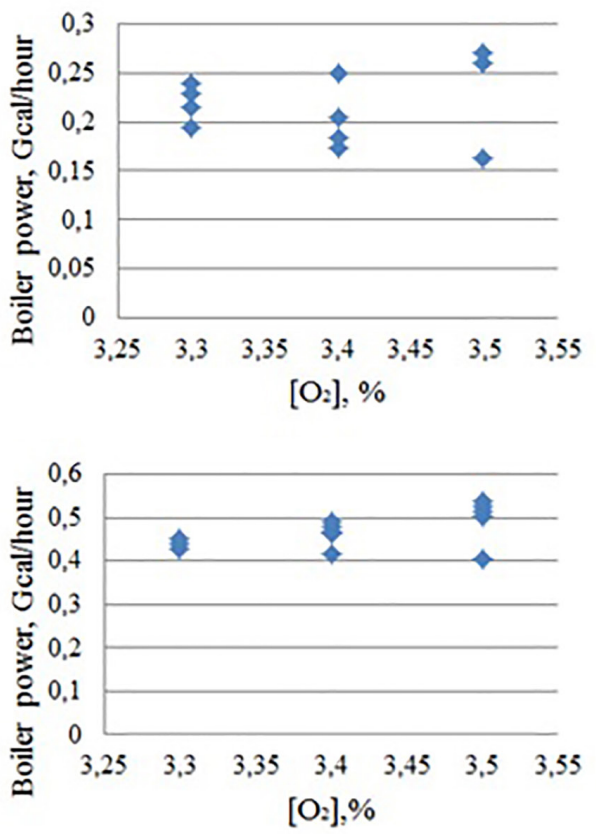

Fig. 6 The experimental results of the dependence of the boiler power from the concentration of residual oxygen in the flue gases at various boiler loads 

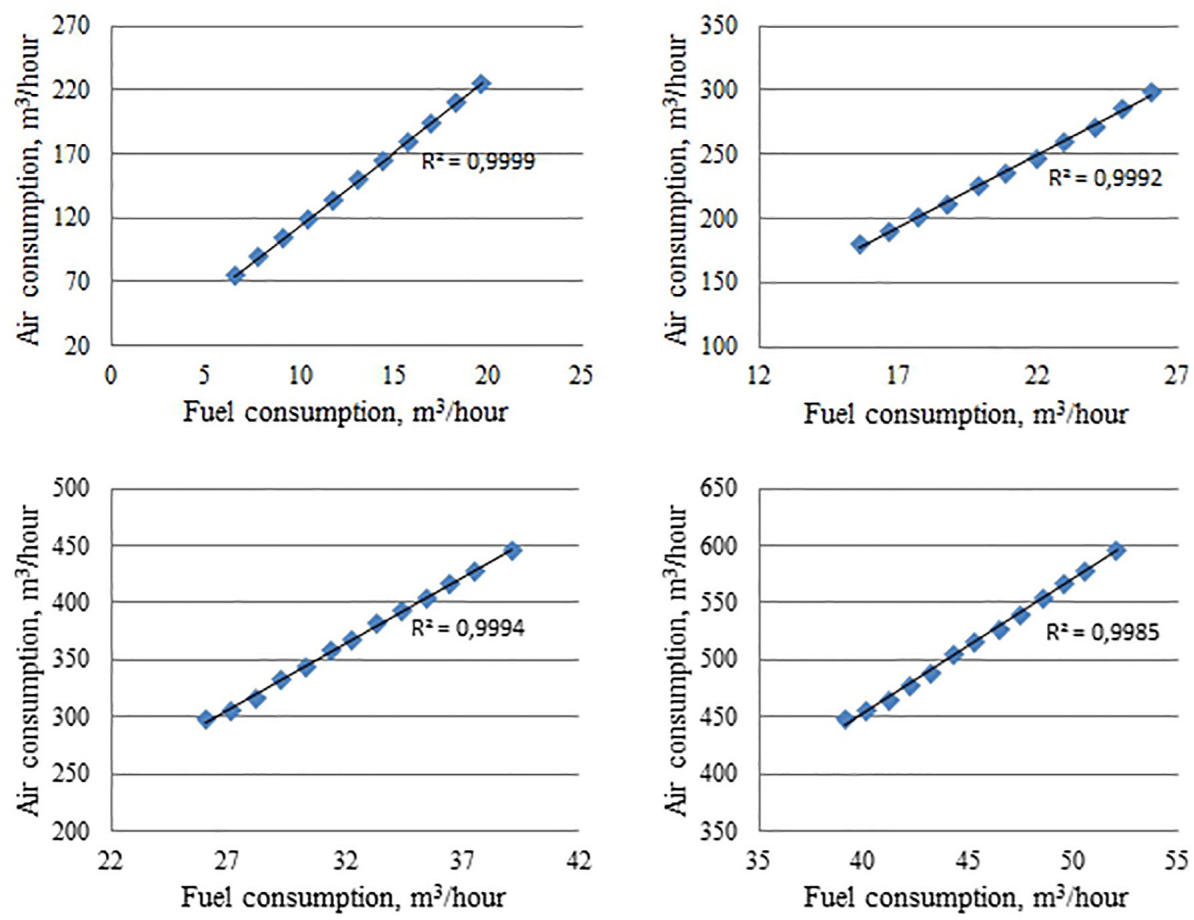

Fig. 7 The value of the air consumption from fuel consumption at various boiler loads

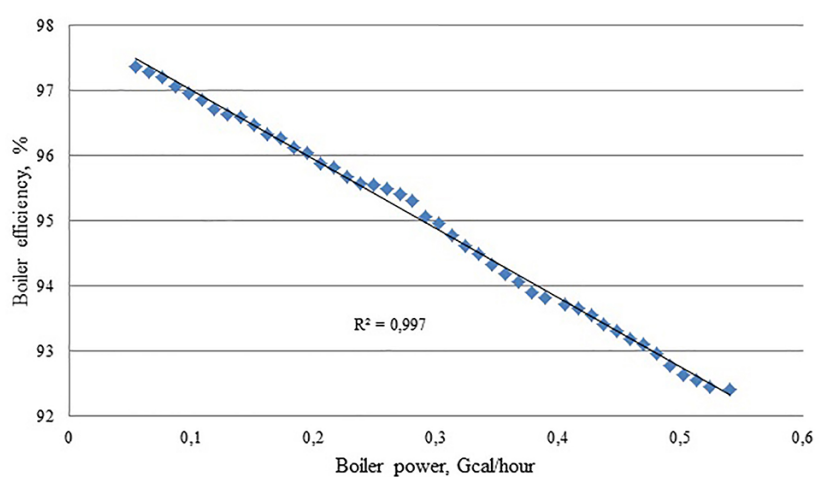

Fig. 8 Dependence of the boiler efficiency from the boiler power

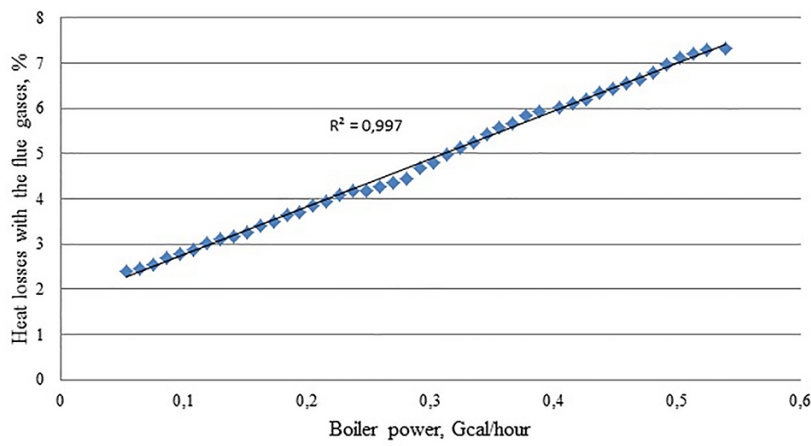

Fig. 9 Dependence of the heat losses with the flue gases from the boiler power

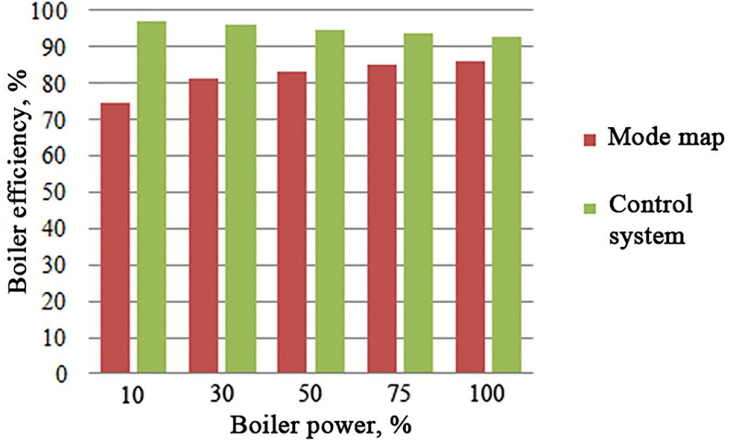

Fig. 10 Comparison of the boiler efficiency with a mode map and with automatic control system based on broadband oxygen sensor

\subsection{Analysis of boiler operation on the basis of the control system}

In the course of the experimental studies, it has been observed the levels of $\mathrm{CO}$ and NO concentrations in the flue gases. The dependence of their changing from the boiler power shows the Fig. 11.

It is showing on the Fig. 11 that the concentrations of $\mathrm{CO}$ and $\mathrm{NO}$ in combustion products decreases when the boiler power increase from $10 \%$ to $\sim 50 \%$. With a further increasing of boiler power, the $\mathrm{CO}$ concentration tends to increase. In general, the $\mathrm{CO}$ concentration in the combustion products over the entire measurement range was from $10 \mathrm{ppm}$ to $40 \mathrm{ppm}$. This indicates the minimization of chemical 


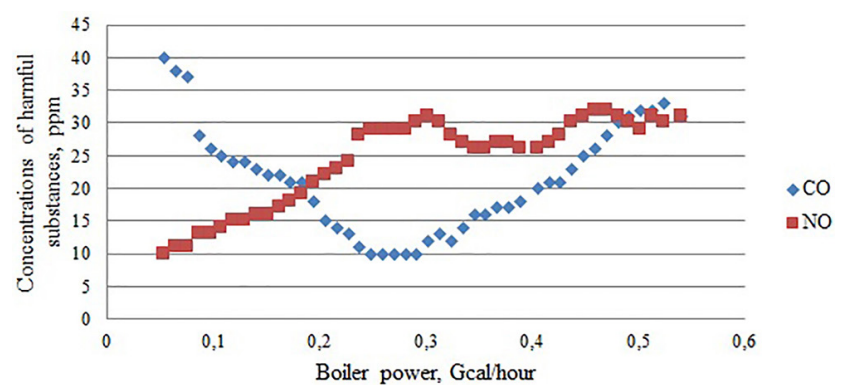

Fig. 11 Dependence of CO and NO concentrations in the flue gases from the boiler power

underburning in the boiler furnace and the possibility of further application of the developed system without $\mathrm{CO}$ sensors. With further increasing of boiler power, the NO concentration in the combustion products increased in the range from $10 \mathrm{ppm}$ to $32 \mathrm{ppm}$ with local minima of $26 \mathrm{ppm}$ at powers of $0.34 \mathrm{Gcal} /$ hour and $0.40 \mathrm{Gcal} /$ hour.

The received results testify that the developed system provides combustion of fuel within the limits of permissible concentrations of $\mathrm{CO}$ and NO harmful substances in combustion products $(<50 \mathrm{ppm})$ and allows to maintain the level of harmful substances in the flue gases within the limits of specifications.

\subsection{Economic analysis}

The beginning/end of the heating season occurs when the average daily air temperature is less/more than $+8^{\circ} \mathrm{C}$. As the ambient temperature during the heating season varies in a fairly wide range, the amount of necessary heat energy for maintaining the necessary temperature conditions in the premises is not a constant.

The relationship between the ambient temperature and the boiler operation power is established on the basis of experimental studies. For studying the economic indicators of the developed system, the dependence on the Fig. 12 is used.

Thus, the boiler power $F$ (in a percentage ratio) during the heating period was determined by the formula:

$F=3 \cdot T+55$,

where $T$ - air temperature.

The dependence of the boiler power on the basis of the developed control system for the combustion process during the heating period in Kyiv is shown in Fig. 13.

Fig. 14 shows the graphs of the changing of the boiler efficiency during the heating season on the basis of the developed system for automatic control of the fuel combustion process and the mode map for Kyiv.

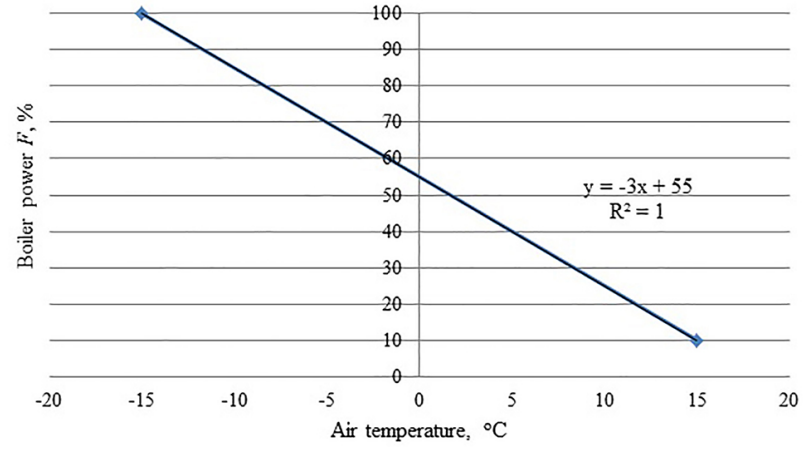

Fig. 12 Dependence of boiler power from air temperature for boiler NIISTU-5

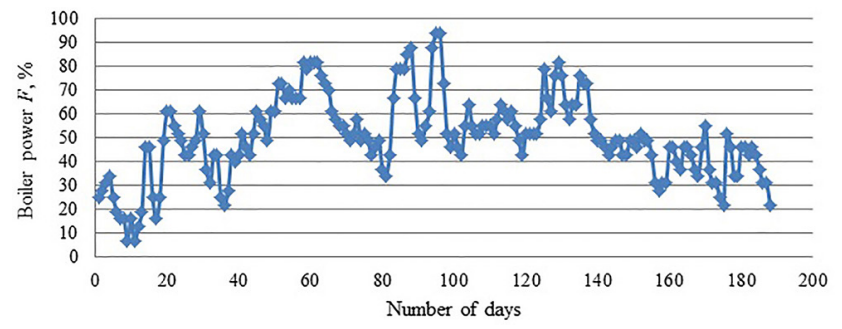

Fig. 13 Changing the boiler power based on the developed automatic control system during the heating season

Thus, it can be argued that the efficiency of the boiler with the fuel combustion control system is higher on $\sim 10-20 \%$ than a mode map is used.

\section{Conclusion}

On the basis of the PBGM-type burner with the developed fuel combustion control system, commissioning and operational testing of the NIISTU-5 boiler was carried out. The obtained results testify the possibility of highly efficient using of obsolete boiler units by replacing the burner with the developed system.

Thus, the using of the developed system allows:

- to increase the efficiency of fuel combustion taking into account actual conditions, operating conditions and fuel characteristics;

- to increase boiler efficiency up to $20 \%$;

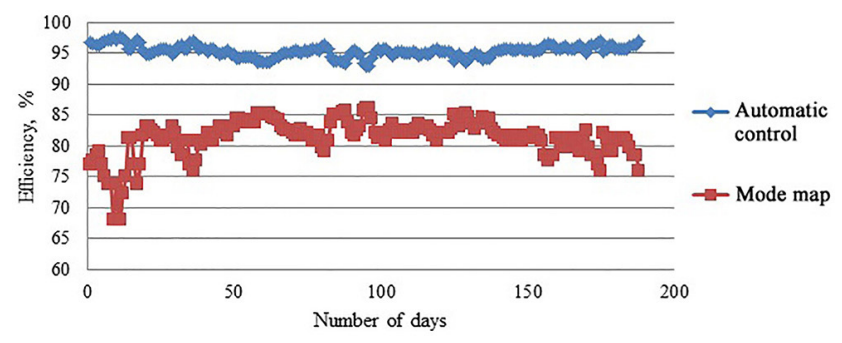

Fig. 14 Comparison of the efficiency of boilers on the basis of the developed automatic control system and the mode map during the heating season 
- to maintain the highest possible efficiency at any operating conditions of the boiler;

- to reduce heat losses with flue gases on $13 \%$;

- to minimize the heat losses with chemical underburning of the fuel $(<0.01 \%)$;

- to maintain a stable EAR for ensuring completely combustion of fuel;

- to increase the service life of the traction mechanisms by reducing the fan motor speed.

\section{References}

[1] Qu, M., Abdelaziz, O., Yin, H. "New configurations of a heat recovery absorption heat pump integrated with a natural gas boiler efficiency improvement", Energy Conversion and Management, 87, pp. 175-184, 2014.

https://doi.org/10.1016/j.enconman.2014.06.083

[2] Gupta, R. D., Ghai, S., Jain, A. "Energy Efficiency Improvement Strategies for Industrial Boilers: A Case Study", Journal of Enginnering and Technology, 1(1), pp. 52-56, 2011. https://doi.org/10.4103/0976-8580.74541

[3] Xu, G., Huang, S., Yang, Y., Wu, Y., Zhang, K., Xu. C. "Technoeconomic analysis and optimization of the heat recovery of utility boiler flue gas", Applied Energy, 112, pp. 907-917, 2013. https://doi.org/10.1016/j.apenergy.2013.04.048

[4] Semkov, K., Mooney, E., Connolly, M., Adley, C. "Efficiency improvement through waste heat reduction", Applied Thermal Engineering, 70(1), pp. 716-722, 2014.

https://doi.org/10.1016/j.applthermaleng.2014.05.030

[5] Regulagadda, P., Dincer, I., Naterer, G. F. "Exergy analysis of a thermal power plant with measured boiler and turbine losses", Applied Thermal Engineering, 30(8-9), pp. 970-976, 2010. https://doi.org/10.1016/j.applthermaleng.2010.01.008

[6] Saidur, R., Ahamed, J. U., Masjuki, H. H. "Energy, exergy and economic analysis of industrial boilers", Energy Policy, 38(5), pp. $2188-2197,2010$. https://doi.org/10.1016/j.enpol.2009.11.087

[7] Chao, X., Jeffries, J. B., Hanson, R. K. "Development of laser absorption techniques for real-time, in-situ dual-species monitoring $\left(\mathrm{NO} / \mathrm{NH}_{3}, \mathrm{CO} / \mathrm{O}_{2}\right)$ in combustion exhaust", Proceedings of the Combustion Institute, 34(2), pp. 3583-3592, 2013. https://doi.org/10.1016/j.proci.2012.05.024

[8] Liu, H., Chaney, J., Li, J., Sun, C. "Control of NOx emissions of a domestic/small-scale biomass pellet boiler by air staging", Fuel, 103, pp. 792-798, 2013. https://doi.org/10.1016/j.fuel.2012.10.028

[9] Pital, J., Mižák, J. "Computational intelligence and low cost sensors in biomass combustion process", In: 2013 IEEE Symposium on Computational Intelligence in Control and Automation (CICA), Singapore, Singapore, 2013, pp. 181-184.

https://doi.org/10.1109/CICA.2013.6611681
The ecological analysis of the system's efficiency showed the possibility of fuel combustion with emission of harmful substances $\left(\mathrm{CO}\right.$ and $\left.\mathrm{NO}_{\mathrm{x}}\right)$ in flue gases at a level not exceeding $50 \mathrm{ppm}$.

Economic analysis of the system's efficiency has shown that the payback of implementation is less than one heating season.

[10] Houshfar, E., Skreiberg, Ø., Løvås, T., Todorović, D., Sørum, L. "Effect of Excess Air Ratio and Temperature on NOx Emission from Grate Combustion of Biomass in the Staged Air Combustion Scenario", Energy\&Fuels, 25(10), pp. 4643-4654, 2011. https://doi.org/10.1021/ef200714d

[11] Babak, V, Mokiychuk, V., Zaporozhets, A., Redko, O. "Improving the efficiency of fuel combustion with regard to the uncertainty of measuring oxygen concentration", Eastern-European Journal of Enterprise Technologies, 6(8), pp. 54-59, 2016. https://doi.org/10.15587/1729-4061.2016.85408

[12] Kalicka, Z., Jerzak, W., Cebula, E. K. "The Effect of Combution of Natural Gas With 21-29\% $\mathrm{O}_{2} / \mathrm{CO}_{2} / \mathrm{N}_{2}$ Mixtures on Emission of Carbon Monoxide", Archives of Environmental Protection, 39(4), pp. 93-103, 2013.

https://doi.org/10.2478/aep-2013-0033

[13] Heil, P., Toporov, D., Förster, M., Kneer, R. "Experimental investigation on the effect of $\mathrm{O}_{2}$ and $\mathrm{CO}_{2}$ on burning rates during oxyfuel combustion of methane", Proceedings of the Combustion Institute, 33(2), pp. 3407-3413, 2011.

https://oi.org/10.1016/j.proci.2010.05.047

[14] Zaporozhets, A. O., Redko, O. O., Babak, V. P., Eremenko, V. S., Mokiychuk, V. M. "Method of indirect measurement of oxygen concentration in the air", Scientific Bulletin of National Mining University, 5, pp. 105-114, 2018.

https://oi.org/10.29202/nvngu/2018-5/14

[15] Zaporozhets, A., Eremenko, V., Serhiienko, R., Ivanov, S. "Methods and Hardware for Diagnosing Thermal Power Equipment Based on Smart Grid Technology", In: Shakhovska, N., Medykovskyy, M. (eds.) Advances in Intelligent Systems and Computing III. CSIT 2018. Advances in Intelligent Systems and Computing, Vol. 871, Springer, Cham, Switzerland, pp. 476-489. https://doi.org/10.1007/978-3-030-01069-0_34

[16] Zaporozhets, A. A., Eremenko, V. S., Serhiienko, R. V., Ivanov, S. A. "Development of an Intelligent System for Diagnosing the Technical Condition of the Heat Power Equipment", In: 2018 IEEE 13th International Scientific and Technical Conference on Computer Sciences and Information Technologies (CSIT), Lviv, Ukraine, 2018, pp. 48-51.

https://doi.org/10.1109/STC-CSIT.2018.8526742 